\title{
Second person narrative in War Documentaries
}

\author{
Luiz Augusto Coimbra de Rezende Filho
}

Federal University of Rio de Janeiro, Brazil

\begin{abstract}
Cinematic-letters have been an important modality of using a second-person narrative in documentary films. Several filmmakers, such as Marker, Varda, Mekas and Kramer, dedicated themselves to construct and redefine this modality as a non-hegemonic form of documentary and/or as an explicit way to put subjectivity at the foreground.

Second person narratives represent a specific strategy to interpellate spectators. Interpellation is "the recognition of someone, who in turn is expected to recognize himself as the immediate interlocutor" (Rascaroli 2009). If address and interpellation are always present in documentary narrative, whether first, second-, or third-person, second person narratives can make the presence and the existence of a "you" explicit, creating thus a specific form of spectator's participation.

In A Diary for Timothy (Jennings 1945), second person narrative has the potential to make explicit a form of address that challenged spectators to leave their comfort zone, and face the uneasy feeling of being the addressed ones. Thus, the film created a specific form of spectator participation in documentary cinema.

Similarly, Strange Victory (Hurwitz 1948) "combines reedited archival footage with scenes of contemporary America and acted sequences" with "a male voice over addressing the viewers directly and expressing a sense of urgency and anger" (Decker 2011). As in Timothy, this second person voice-over helps constructing opposition and/or identification relations between the documentary voice and the spectator, in order to deconstruct the vision of a unified nation or emphasize its internal violence and disunity (Decker 2011).
\end{abstract}

Keywords: Second Person Narrative, Modes of Address, Voice-over, Documentary Spectatorship, War Documentaries

\section{Introduction}

Recent discussions about non-hegemonic models of documentary narrative have stressed the relevance of new forms of documentary subjectivity expression, especially those modulating the filmmaker's voice. These voices have evolved from a supposedly neutral, invisible and unidentified third-person to a kind of expression in which the filmmaker presents himself as an identified and/or visible character in the narrative.

War times made war cinema to become "almighty", according to Jean-Louis Comolli (2008). War documentaries were well known for their "bad examples" of montage and voice-over use, in which the neutral and invisible third person narrator became hegemonic and authoritarian. These were some of the reasons why criticism grew against this modality of documentary, giving birth to strategies such as first person narration. Herein I analyze how two post-war documentaries, A Diary for Timothy (Jennings, Great-Britain, 1945) and Strange Victory (Hurwitz, USA, 1948), although made during a time of God's third voice narration style prevalence, made up second person voice-over a strategy to address and instigate spectators into participation.

Among first person narratives in documentary, there are some that stand out, like the essay and the cinematicletter. These are strategies of which the objective is not only to move the narrative point of view, but also to address the spectator in different ways, displacing formerly assumed suppositions or understandings. Documentary letters have Letter from Siberia (France, 1959), by director Chris Marker, as one of its most notorious representatives. In this film an abstract and undefined recipient (a general "you") helps to identify the source of the discourse, in order to situate the narrative as a critical reasoning about the filmmaker's own impossibilities of reporting with neutrality and objectivity. In another Chris Marker's film, Le Tombeau d'Alexandre (France, 1993), we found again the structure and the strategy of a cinematic-letter as homage to a friend, the soviet film director Aleksandr Medvedkin, and as a means to debate his legacy. In this film, the "you" addressed by the letter is not an unidentified person, but the deceased soviet director himself.

But cinematic-letters have also been an important modality of using second-person narrative in documentary film, by combining both first and second person narratives. Several filmmakers have dedicated themselves to construct and redefine this modality as a non-hegemonic form of documentary or as an explicit way to put subjectivity at the foreground, giving space for one of the most common forms of essay in cinema. Besides Marker, other filmmakers such as Jean-Luc Godard, Agnes Varda, Jonas Mekas, Robert Kramer, Chantal Akerman have made important contributions to this modality.

To start this analysis, I want to consider the discursive theoretical background structuring second person narratives. Second person documentary, differently from third person narratives, supposes the existence of interlocution between two "speakers". Thus it implies knowing what/who is the second person, by contrast with a third- and a first-person, as they are supposedly and grammatically defined. In Literature, second person narration usually does not make use of a main character, since it is supposed the lector (or spectator in cinema) would take this position. In cinema, second person can be identified by direct address through an eye-line match with the camera and voice-over commentary or dialogue that speaks to a "you", mostly the viewer, but sometimes also a character. That is what happens in both films analyzed here, A Diary for Timothy and Strange Victory.

For Paul Ricoeur, saying "I" implies supposing the existence of a "You" (Rascaroli 2009,14). That is 
possibly why first person documentaries frequently address a second person, a "You". And likewise, "You" must imply an "I". That is possibly why cine-letters usually combine first- and second- person narration.

According to Laura Rascaroli, in her book "The Personal Camera":

\begin{abstract}
Structuralism and enunciation theory have rightly been critiqued for presenting an abstract image of the reader/spectator, who used to be seen as a viewing position, as a standardized and passive figure produced and controlled by the text. The subjective enunciators of first-person films often address spectators directly, sometimes by looking into the camera lens, or else by speaking to them, or simply by presenting their discourse as a confession, as a shared reflection, or as a persuasive argument. My claim is that the (real) spectators of these films are called upon in an unremitting effect of interpellation. (RASCAROLI: 2009, 14).
\end{abstract}

So, for the author, there is a similarity in first person and second person narration strategies, a similarity that she defines as "an unremitting effect of interpellation" in both, whether by looking into the camera lens or by speaking to this "You": the spectator, or a designated character. Nevertheless, and although first person documentaries may incorporate second person address, these two strategies have different and specific effects in spectatorship.

Second person narratives represent a specific way and strategy of interpellation to the spectator. As defined by Rascaroli, drawing from Casetti's theory, Interpellation is "the recognition of someone, who in turn is expected to recognize himself as the immediate interlocutor" - like in the formula "I am talking to you". It presupposes the idea of asking a question to the spectator, assigning him or her a task or future, etc. But, how much may the "I" be hidden or undefined in first and second person narratives? May third person narratives do it in the same way?

\section{Second Person Documentary Narrative Strategies}

How are second person narratives made in documentary films? The easy answer is by either a voice or a look addressed to the camera, as said before (Rascaroli 2009). But that seems not enough to answer this question since addressing and interpellation are always present in documentary films, disregarding of the narrative strategy adopted, whether first-, secondor third-person. Addressing and interpellation are inevitable in cinema and communication. Nevertheless second person narratives can make explicit the presence and the existence of a "you" and the differences in the modes of addressing and constructing opposition or identification relations between the voice of the film (the supposed "I") and the spectator in order to create "participation". As commented by Rascaroli: If "voice-over is the privileged site of the textual construction of the enunciator" and "an instrument of expression of the author's subjectivity and thought"
(Rascaroli 2009, 16), then it is also for interpellation and addressing. Nevertheless, second person voice-over does not necessarily expresses directly or immediately the author's subjectivity and thought. That is a point in which first person and second person narration strategies separate, since second person narration tends to hide or to bypass the "I" in order to make explicit the "you" and his or her identity.

A Diary for Timothy, a 1945 short film directed by Humphrey Jennings in Great Britain, presents, according to a synopsis found in the IMDB website, "the status of Great Britain near the end of World War II by means of a visual diary for a baby boy born in September, 1944. Narrator explains to 'Timothy' [the baby] what his family, his neighbors, and his fellow citizens are going through as the war nears its end, and what problems may remain for new Englishmen like Timothy to solve". Timothy is addressed by a voice-over as a cine-letter that talks to him (as "you") all the time. Other characters appear (such as Goronwy, the miner; Alan, the farmer; engine driver Bill; The pilot, Peter Roper). But they are never addressed as Timothy is: they are presented as examples of what people have been doing during war years for the country and for the safety of babies like Timothy. In this film, the recipient of the letter is not, at least to some extent, an abstract, general and random "you": it is a defined character. It is an "other" to the spectator. Since the letter is not addressed to a generic or unidentified self, spectators can feel empathy for Timothy - more than identification. Since there is not a dialogue, because there is no alternation of turns of speech, and no chance of immediate response, Timothy is not only the object of empathy to a third party (the audience), but also the bearer of the public's acquiescence to what is said to him, as in the film's voice-over:

\footnotetext{
- We had feeling too deep that we were to fight for you... you and all the other babies.

- We feel confident enough now to remove the mines... Then nothing will interpose between you and the sea.

- However, you are in danger. Yes in danger, Tim!

Around you is the worst war ever known.
}

Nevertheless, this comfortable place of a third-person to the audience, which seems, to some extent, to exclude the spectator of the "debt" Timothy and the other babies have to the war effort, will be broken in the last minutes of the film. The voice-over changes its mode of address and interpellation away from the stable and visible recipient of the discourse (Tim) to the spectator him/herself. Although still addressed to Timothy, it changes to a different tone:

\footnotetext{
- Well, dear Tim, this is what is happening around you. So far we were talking. More quickly you will have to put you on guard. What will you say about it? What are you doing? It will be like that again? Are you going to have greed for money or power, expelling the decency from the world just like in the past? Or are you going to make the world a different place, you and the other babies?
} 
These are the last words in the film. Now Tim is differently interpellated. Now is his turn. And he has to take the lead and do it better. But there is another layer in this voice, addressed to those who were in the world before Tim, and who made the war. There has been greed for money and power and lack of decency before Tim was born. The attribution of this guilt breaks the distance in the indirect interpellation and suddenly Tim (the "you" so far), is substituted by the spectator, those who were, in a collective way, responsible for the war. Tim has always been an indirect recipient of the letter. Then the spectator is forced to leave his comfort zone, not to adopt the false subjectivity of another, like in Hollywood fiction cinema, but to face the uneasy feeling of being the addressed one when the accusation turns to the other side of the screen. At least, as far as we consider this strategy was directed and intended in the first place to the British audience in 1945. Otherwise this understanding would have to be adapted by the spectators. Anyway it seems it would work towards the same direction in any case since this is a discursive and narrative strategy of the film.

Thus in A Diary for Timothy, second person narrative represents a specific way and strategy of addressing. Interpellation works beyond of asking a question to the spectator: it calls the spectator out to his responsibilities, even if this happens in a moralistic or unfruitful way. Although addressing and interpellation are always present in documentary films, second person narratives have the potential to make it explicit since spectator may be conducted to see him/herself directly implicated as the "you" addressed by the narrative. This is a specific form of creating "participation" in cinema.

Addressing in Timothy, however, cannot be understood as the act of making present a real recipient. On the contrary, it seems to be a strategy to invite the spectator to a position that breaks from the safe feeling of empathy for someone else to the sudden recognition of being the one addressed by the voice-over. With all the consequences this might have.

Strange Victory, a long feature film directed by Leo Hurwitz in 1948, is about the "racial bias in post World War II" North America, according to a synopsis found in the IMDB website. The documentary focuses on the effects of prejudice and segregation against Black and Jewish people, lying beneath the apparent peacefulness of post-war days. The film follows the understanding according to what World War II was a "two-fronted fight" for Americans and the "domestic battle" was even more urgent (Shiffman 2007). Its thesis is about the persistency of fascism in post war American society, in which "the ideas of the loser are still active in the land of winner", according to the film voice-over. And that is a "strange victory".

Christof Decker describes Strange Victory as combining "reedited archival footage with scenes of contemporary America and acted sequences" and "a male voice-over addressing the viewers directly and expressing a sense of urgency and anger" (Decker 2011). Writing about the reception of Strange Victory in a special screening held during a Conference for
Alternative Cinema in 1979, Jeffrey Youdelman reports that:

the audience was mesmerized by a style of filmmaking most had not seen before: a film composed by the now rejected method of montage, full of varied sequences, mixing newsreel and acted episodes. The film is held together by a narrative voice that assumes many styles and personas and by an overall structure that the writer Warren Miller described as "so complex it would require diagrams to explain it". (YOULDELMAN: 1988).

Considered very innovative for its time, whether for its theme or aesthetics, Strange Victory voice-over is a mixture of strategies itself. Although not entirely in second person narration, the documentary has two very important sequences using this kind of narrative.

The first one takes approximately 17 minutes of the film, that is almost $1 / 3$ of it, and "presents the life and the world" to a series of new born babies and small children, black, white and Jewish. Initially a woman's maternal voice, supposedly that of a pregnant woman sitting peacefully in a public bench, speaks to the children about their future. She explains them the worthiness of every single life, the need to go ahead despite of difficulties and their belonging to their time and land whoever they are. "Rest now, sleep now", she says. "Where you go? You go everywhere! What will you do? You'll do everything!", she motivates them. "And whose world is it? Its yours for making it!", she sums up. This is the only case of an identified "l" (the pregnant woman) speaking to a generic and abstract "you", the children representing the future of the country.

After that, a more severe man's voice changes the subject and the tone, keeping the same recipient of his message, the babies and children. Now they are presented to the "plain facts" they will be facing in their life and that they must learn. First, "who are you?". The differences among them, the color of their skins for example, are made explicit: blacks and whites have different positions in life. These differences are the facts that they will live by, according to the film. As the narration follows, it explains to a Black baby how his access to housing, food, labor will be different form others, and how his life will be limited by this, showing examples of how Black people are submitted to several kinds of segregation in their lives. As words of advice, the man's voice tells everyone: "the world is already arranged for you", followed by images and evidences of segregation.

In a way very similar to that found in A Diary for Timothy, the presence of a "you" in the discourse supposes an "I" or an "us". Although the theme and the focus of the messages are very different, the communication strategies are very similar. As much as in A Diary for Timothy, the recipients of these advices are not an abstract, general and random "you". This "you" is a defined character, representing a group. This group is an "other" to the spectator. Likewise, since the discourse is addressed to visible beings, spectators can feel empathy for them, as in Timothy.

The next occurrence of the second person narration 
appears in the black pilot sequence, a half fictional character, in a dramatized situation. He represents the segregation Black people are submitted to in the employment hierarchy. As he enters a hangar full of planes, the voice-over tells him: "this belongs to you". Although the spectator is conducted to believe he has fought in war, and helped to eliminate the Nazi menace, he is unable to get a job as a pilot. The contradiction stated by the shock between the drama presented and the rights expressed by the voice-over becomes clear: it doesn't belong to him. The voice presents then data to make evident how Black people are excluded form most well paying jobs, and restricted to low paying labor.

As in A Diary for Timothy, the use of a second person voice-over in both sequences helps constructing opposition and/or identification relations between the documentary voice and the spectator to deconstruct the vision of a unified nation or emphasize its internal violence and disunity (Decker 2011).

\section{Conclusion}

First-, second- and third-person narratives not only construct different communicative strategies. They also differently construct forms of addressing the spectator. How they stimulate different viewing positions and different responses of the audience? What modalities of reading are differently encouraged? What is the spectatorial pact they set up? These are questions yet to be answered.

In both documentaries analyzed here, it is visible how the second person narrative strategy fosters a different perspective for spectator participation. As mentioned above, by using direct address, the narratives displaced spectators' positions and stimulated them to move from one character to another with some empathy for them, or even as if they were looking to a strange mirror. In both films, the identification of the voice-over source (the speaking "I") only happened once, even thought in an unsure way. On the other hand the recipients were always visible or identified. This is an important difference to first person narratives and an evident approximation of second person narrative to third person narratives and their objectives. First person narratives must identify their "I". Third person narratives are almost forbidden to do that. This might be explained by the historical background of the films and by their need to interfere in reality by means of fostering a strong commitment of spectators or by a change of perspective, statement needing more research.

What is implied in enhancing and reflecting about these subtle differences are the different forms of addressing they imply and consequently the different communicative strategies and positions constructed to the spectators that compel them to some kind of participation. As in fiction, documentary narrative is clearly constructing a place for the spectator to enter and engage in discourse.

\section{Bibliography}

BRUZZI, Susan. 2000 New Documentary: A Critical Introduction. London and New York: Routledge.

COMOLLI, Jean Louis. 2008. Mauvaises frequentations: document et spectacle. In: Images documentaires, n. 63, Regard sur les archives. Paris.

DECKER, Christof. 2011. Image History: Compilation Film and the Nation at War. In Screening the Americas Narration of Nation in Documentary Film. 2011. Organizado por RAAB, Josef; THIES, Sebastian; NOLL-OPITZ, Daniela. Wissenschaftlicher Editor: Trier.

GRANT, Barry G. \& SLONIOWSKI, Jim (orgs.). 2014. Documenting the Documentary - Close Readings of Documentary Film and Video. Detroit: Wayne State University Press.

RASCAROLI, Laura. 2009. The personal camera: subjective cinema and the essay film. London: Wallflower.

RENOV, Michael. 2004. The Subject of Documentary. University of Minnesota Press, Minneapolis.

SHIFFMAN, Dan. 2007. Richard Wright's "12 Million Black Voices" and World War II-era Civic Nationalism. In: African American Review Vol. 41, No. 3, pp. 443-458.

YOUDELMAN, Jeffrey. 1988. Narration, Invention, and History, in New Challenges for Documentary. Organizado por ROSENTHAL, Alan. 1988. Los Angeles: University of California Press. 